
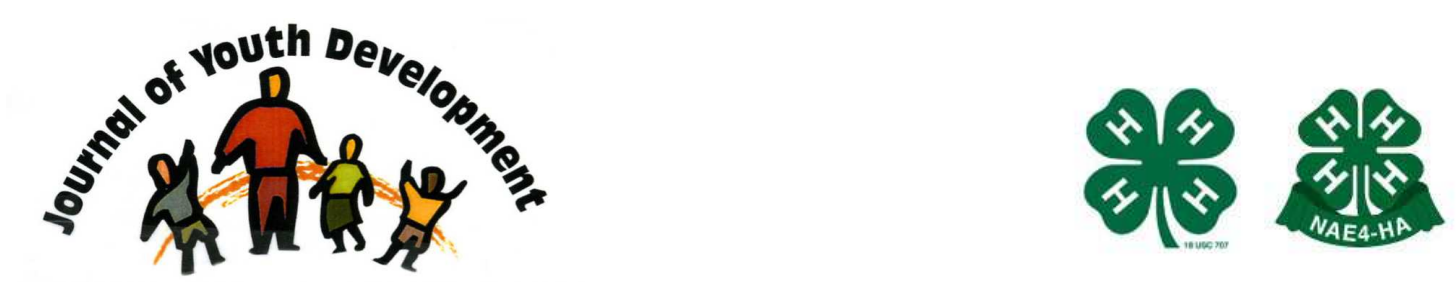

Bridging Research \& Practice

\title{
The First Eight Years Giving Kids a Foundation for a Lifetime Success Resource Review
}

\author{
Patricia Dawson
}

Oregon State University 


\title{
JOURNAL OF YOUTH DEVELOPMENT \\ bridging research and practice

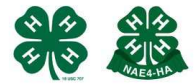

Volume 8, Number 3, Winter 2013

Article 130803RR001

\section{The First Eight Years \\ Giving Kids a Foundation for a Lifetime Success \\ Resource Review}

Patricia Dawson

Oregon State University

\begin{abstract}
The First Eight Years: Giving Kids a Foundation for a Lifetime Success" is a recent KIDS COUNT policy report from the Annie E. Casey Foundation. The report discusses how a child's early development from birth through age 8 is critical in one's transition into elementary school as well as long-term academic success. The report also provides broad policy recommendations to help America's children succeed and data on early childhood development for every state.
\end{abstract}

\section{Review}

The latest KIDS COUNT policy report from the Annie E. Casey Foundation "The First Eight Years $\sim$ Giving Kids a Foundation for a Lifetime Success" focuses on the importance of investing in the early years of a child's life. The 20 page report details how a child's early development in critical areas of well-being leads to a successful transition into elementary school and ultimately long-term success in the school system. The report addresses the importance of classroom learning integration with other aspects of child development including social, emotional and physical development for youth to develop the full cadre of competencies they will need to succeed in life.

The report highlights three broad policy recommendations to prepare America's children for success:

- Support parents so they can effectively care and provide for their children.

- Increase access to high-quality birth-through 8 programs.

- Develop comprehensive, integrated programs and data systems to address all aspects of children's development and support youth transition to elementary school as well as related programs for school-aged youth. 
Readers will find the data on early childhood development to be helpful in program development. This policy report highlights indictors of child well-being on a state and national basis. The report also includes numerous helpful data pieces such as a trend analysis of third graders in the four categories of Cognitive Knowledge Skills, Social and Emotional Development, Engagement in School and Physical Well-Being with breakdowns by income, race and Hispanic origin. The report also has a state-by-state breakdown of children birth to 8 living in low-income households. The figure illustrating the educational attainment of head of household with children further emphasizes the struggles low-income families have in supporting their child's educational success.

Overall, this policy report is well structured with helpful data to emphasize key points. While only 20 pages in length, the document is filled with important considerations for all youth development professionals to consider as we work to help establish a foundation for youth success. The report is available at no charge on the Annie E. Casey Foundation website at www.aecf.org.

\section{References}

The Annie E. Casey Foundation. (2013). The First Eight Years Giving Kids a Foundation for Lifetime Success. Policy Report-Kids Count. Baltimore, MD: Author. Retrieved from www.aeacf.org

(C) Copyright of Journal of Youth Development $\sim$ Bridging Research and Practice. Content may not be copied or emailed to multiple sites or posted to a listserv without copyright holder's express written permission. Contact Editor at: patricia.dawson@oregonstate.edu for details. However, users may print, download or email articles for individual use.

ISSN 2325-4009 (Print); ISSN 2325-4017 (Online) 